DOI: https://doi.org/10.32839/2304-5809/2021-6-94-7

удК 811.113

Дун Ці

Національний педагогічний університет імені М.П. Драгоманова

\title{
ДОСЛІДЖЕННЯ ПЕРЕДУМОВ ВИНИКНЕННЯ ПОЛІТИЧНОГО ДИСКУРСУ В АНГЛОМОВНИХ КРАЇНАХ
}

\begin{abstract}
Анотація. Стаття покликана висвітлити передумови виникнення англомовного політичного дискурсу 3 точки зору лінгвістики. У статті зосереджено увагу на поняття «дискурс» та поділ його на види, одним 3 яких є політичний дискурс. Осмислення значення мови як головного чинника політичного дискурсу, так як успішність політичного дискурсу базуеться на влучному вживанні мовних засобів. У рамках лінгвістичних досліджень виокремлюються два підходи до аналізу дискурсів - дескриптивний та критичний. Концептуальну основу мови політики створюе іерархія цінностей з їх високим аргументативним потенціалом. Саме ціннісні структури підтримують міфрологію суспільної свідомості, до якої так, чи інакше апелюють політики. У статті визначено, що політичний дискурс - проблема не тільки політична, але й у неменшій мірі лінгвістична й культурна.
\end{abstract}

Ключові слова: політиний дискурс, дискурс, цінності, лінгвістика.

Qi Dong

National Pedagogical Dragomanov University

\section{STUDY OF THE PRECONDITIONS OF THE ORIGIN OF POLITICAL DISCOURSE IN ENGLISH COUNTRIES}

Summary. The article aims to highlight the preconditions for the emergence of English-language political discourse in terms of linguistics. The article focuses on the concept of "discourse" and its division into types, one of which is political discourse. Understanding the importance of language as a major factor in political discourse, as the success of political discourse is based on the accurate use of language. Within the framework of linguistic research, two approaches to the analysis of discourses are distinguished - descriptive and critical. The conceptual basis of the language of politics is created by the hierarchy of values with their high argumentative potential. It is the value structures that support the mythology of public consciousness, to which politicians appeal in one way or another. The article defines that political discourse is a problem not only political, but also linguistic and cultural. the problem of typology of discourse is an acute problem of linguistic analysis. classification and typification of discourses occupies a prominent place. the result of a large number of typologies of discourse considered by modern scholars are different principles of classification. ethical principles are defining factors in the choice of language shell and are formalized in diplomatic discourse. The main technique of persuasion is propaganda, ie language manipulation of the consciousness of citizens. Political discourse is studied in terms of different areas of socio-humanities, in line with different research approaches. For political science, the main thing is to clarify the political sound of discourse and its impact on the political process. Studies of political discourse from the point of view of philology are mainly based on the study of political texts and the understanding of their ideological intentions. Tactics that implement strategies are considered a tool for consistent achievement of the goal by solving specific communication tasks. In political discourse, which aims to fight for power, the specifics of communicative planning depends on the situation of social interaction of communicators and the characteristics of the linguistic personality of the politician, which are reflected in tactical preferences and, consequently, the choice of language. Under the language strategy, based on this, we will understand a certain direction of language behavior of the politician in a particular situation of language communication, which contributes to the achievement of the predicted communication goal.

Keywords: political discourse, discourse, values, linguistics.

$\Pi^{2}$ остановка проблеми. На сучасному етапі розвитку політичного дискурсу існуе тісний зв'язок між мовою та політикою. Мова є рушійною силою політичного дискурсу, адже за допомогою її ресурсів іде впевнене переконання (аргументація). Роль мови в політикумі активно досліджують фолософи, політологи, психологи, соціолінгвісти, політичні та громадські діячі.

Людство досить недавно усвідомило, здатність мови впливати на політичні процеси. Згідно праць П. Бергера та Т. Лукмана мова дістала обгрунтування вливу та введення термінів, понять, мовних зворотів бути знаряддям політичної мобілізації та стала потужним інформащійним ресурсом у політичних структурах. Мова є головним компонентом самоорганізаціі суспільства. Мова відображається у діях людей та виступає компонентом соціалізації та само- ідентифрікації та виконуе такі фрункції як - естетичну, ідентифікаційну, культуротворчу та інші. Л. Мухарямова відмічае у своїх дослідженнях, що «Сучасний мовний простір фрормується під сильним тиском англійської мови, яка тяжіє до перетворення .у глобальну мову міжнародного спілкування. Її̈ натиск призводить до відчутного зменшення мовної багатоманітності і зникнення мов нечисленних народів. Тріумфральна хода англійської мови, яку нині вважають рідною приблизно 400 млн. чол. і ще більше мільярда використовують як другу, або третю - свідчення тієї ваги, якої набуває в сучасному світі комунікативна фрункція мови. Англійською мовою розміщено 80\% інформації в Інтернеті, в англомовних країнах виробляеться 40\% світового ВВП, англійська мова має офріційний статус у більш як 50 державах» [3, с. 28]. 
Аналіз останніх досліджень і публікацій. Поняттям «дискурс» займалися ряд науковців такі як О. Селіванова, Г. Гук, Ю. Степанов, Н. Кіщенко, Ю. Габермас, Є. Шейгал. Чітко визначив поняття «політичний дискурс» Є. Шейгал, який обгрунтував приналежність політичного дискурсу до інституційного різновиду спілкування.

Виділення не вирішених раніше частин загальної проблеми. Політичний дискурс досліджуеться з погляду на різні галузі соціо-гуманітаристики, в руслі різних дослідницьких підходів. Для політології головним $\epsilon$ вияснення політичного звучання дискурсу і його впливу на політичний процес. Дослідження політичного дискурсу з точки зори філології головним чином базуються на дослідженнях політичних текстів та осмисленнях в них закладених ідеологічних інтенщій.

Однією з найбільш близьких до політики галуззю лінгвістики $е$ політична філологія, яка на основі аналізу мовних особливостей політиків досліджуе співвідношення дискурсу з політичними концептами такими як «влада», «закон», «вплив» та інші. Будь-який, у тому числі й політичний дискурс - явище когнітивне за своєю суттю, оскільки пов'язане із відтворенням і передачею знань.

Мета статті. Метою статті є висвітлення передумов виникнення та становлення політичного дискурсу у розрізі лінгвістичних досліджень.

Виклад основного матеріалу. Найменування цього напрямку вказуе на предмет його дослідження - політична лінгвістика займається дослідженням «політичної комунікації», тобто мовної діяльності, яка оріентована на пропаганду певних ідей, емоційний вплив і спонукання громадян до політичних дій, для прийняття та обтрунтування політичних і сощіальних рішень в умовах багатьох точок зору в соціумі, для вироблення суспільного згоди. Мета політичної лінгвістики полягає в дослідженні різних взаемин між політичним станом суспільства, суб'єктами політичної діяльності, комунікаціею, мисленням і мовою. Саме тому головним завданням політичної лінгвістики $е$ дослідження взаємовідносин між суб'єктами політичної діяльності, комунікацією, мисленням, мовою і політичним станом суспільства. Аналіз дискурсу являе собою міждисциплінарну область знання, яка знаходиться на стику фрілософрiї, стилістики, семіотичного напрямку літературознавства, етнографіï, психології, соціології, лінгвістики. Дискурсійний аналіз здійснюеться з різних позищій, проте існують основні посилки аналізу. До них відносяться:

- текст як комунікаційний продукт має кілька вимірів, основними з яких вважаються інтерпретація і породження тексту;

- комунікація включае посткомунікативну і докомунікативну стадіі;

- головна роль в ситуації комунікації належить не засобам спілкування, а людям;

- спілкування здійснюеться в комунікативних ситуаціях, які зобов'язані досліджуватися в культурному контексті;

- динамічна мовна модель мае базуватися на комунікації, тобто спільній діяльності людей, які намагаються висловити власні почуття, обмінятися досвідом та ідеями або надати один на одного вплив;
- статистична мовна модель не відповідає природі дискурсу і вважається занадто простою.

Увага вчених, які вивчають політичний дискурс, звернуто на аналіз його окремих жанрів: політичний анекдот та новорічне звернення до громадян, політична програма та карикатура, політичний плакат та політичний скандал, парламентські дебати та передвиборна полеміка, листівка та політичне інтерв'ю.

Дискурс - це текст, «занурений у життя», «мова у житті», тобто текст як результат цілеспрямованої соціальної дії, як фокус дій мовних і мовленневих, соціокультурних та прагматичних, когнітивних і психологічних факторів. Таким чином, це не просто мовне/мовленневе формоутворення, яке складніше за окреме речення, яке, як відомо, створюе нові фрізичні дії, ментальні й психічні продукти [2, с. 46]. Проблема типології дискурсу е гострою проблемою лінгвістичного аналізу. Класифікація та типізація дискурсів займае чільне місце. Результатом великої кількості типологій дискурсу, які розглядають сучасні науковці є різні принщипи класифікації [2, с. 49].

В наш час отримали практичну розробку чи були теоретично виділені політичний, діловий, масово-інформаційний та інші типи дискурсу [2, с. 49]. Наукове осмислення такого об’емного об'єкта, як дискурсивний простір, потребуе, з одного боку, чіткого розмежування дослідницької сфери, а з другого - передбачає розробку робочого визначення конкретної одиниці дискурсивного аналізу [2, с. 49].

Ми погоджуемося з дослідженнями Н. Акінчинець, політичний дискурс існуе в усній та письмовій формах. До усних форм відносять (публічний виступ політиків високого рангу, їх інтервю, виступ на радіо та телебаченні, пресконференції, парламентські дебати, блоки політичних новин в теле- і радіопередачах) опираючись на шаблон розроблений у давні часи. Індивідуальність має особову форму. У спілкуванні, що включае інститути, виділяються жанри, які характерні для суспільно-інституційної комунікації (лінія «суспільство - інститут»: виступи на мітингах, накази виборців, листівки, звернення, петиції; лінія «інститут - суспільство»: указ президента, радіозвернення, публічні промови політиків, плакати, гасла, заклики, закони, декрети, постанови уряду), комунікації між агентами в інститутах (публічна сфера: програмна промова на партійному з'їзді, партійна програма, доповідь на з'їзді, виступ прем'єр-міністра на засіданні Верховної Ради, круглий стіл, парламентські дискусії, зустрічі політичних діячів, переговори; внутрішня сфера: закрите засідання, кулуарне обговорення, службове листування та ін.), комунікації між громадянином і інститутом (голосування на виборах, листи громадян до інститутів і політикам, телеграми).

Соціокультурна диференціація жанрів дискурсу в сфері політичної комунікації, яка веде до формування політичних соціолектів, обумовлена різнорідністю ідеологічних орієнтацій групових політичних суб'єктів. Ідеологічна оріентація закладена в основу політичного соціолекта і визначає його номінативний автономний код, який утворений головними словами-ідеологемами, специфрічним набором мовних тактик, стратегій і жанрів. Аргументація в такому випадку при- 
ймається в єдності вербального, невербального і екстралінгвістичного. До письмової фрорми належать різного роду договори, домовленості, протоколи, а також друковані видання, преса ( секції, відведенні для розміщення політичних фактів). Політична реклама також виступає частиною письмової форми (буклети, плакати, агітки). Головна відмінність політичного дискурсу від інших видів аргументативних дискурсів (юридичного, академічного, рекламного, побутового, виробничого ) полягає в його явно вираженій апеляції до цінністної системи, існуючої в певному суспільстві [1, с. 75]. Пропаганда являеться основною технікою переконання це мовне маніпулювання свідомістю громадян та важілем впливу суб'єктивної думки. Ціннісна орієнтація обумовлює широке використання лексичних одиниць 3 оціночним (здебільшого позитивним) значенням, що позначають, головним чином, систему політичних цінностей (свобода, демократія, вибір, рівність і таке інше). Можна виділити наступні критерії, які визначають рівень маргінальності або прототипних жанрових форм: відповідністю головною інтенції політичного дискурсу - первинність тексту, боротьбі за владу і наявністю або відсутністю перетину з іншими типами дискурсу. До прототипних жанровим формам, виходячи 3 цього, Є.I. Шейгал відносить первинні, інституційні жанри: переговори та декрети, гасла та публічні політичні промови, парламентські дебати. Політичні периферійні жанри вважаються вторинними жанрами, вони знаходяться на перетині 3 іншими типами дискурсу. Ці жанри мають респонсивний характер: анекдот та пародія, політична карикатура та графріті, листи читачів та аналітичні статті, політичні мемуари та інтерв'ю тощо. У фрункці- ональній структурі простору жанру Є.I. Шейгал виділяе епідейктичні / ритуальні жанри. Головною інтенцією епідейктичності жанрів вважається інтеграція (ювілейна промова, радіозвернення, інавгураційна промова та гасло), а також орієнтаційні жанри (угоду, указ і конституція) [4, с. 244-245]. Під мовною поведінкою суб'єкта політичного дискурсу слід розуміти складне багатогранне явище, яке детерміновано інтенціями комуніканта. Політики в боротьбі за владу використовують всі допустимі засоби, а автори політичних текстів ретельно відбирають тактики і стратегії реалізації політичного дискурсу. Мовні стратегії реалізують мовні жанри та фpopмують їх неповторність та індивідуальність. Для реалізації комунікативної стратегії застосовується набір тактик, які зумовлені інтенціями мовця і представлені сукупністю прийомів, що обумовлюють використання мовних засобів.

Висновки i пропозиції. Політичний дискурс це вид дискурсу, технології якого покликані впливати на думки виборців та досягати запланованих результатів. Тактики, що реалізують стратегії, вважаються інструментом послідовного досягнення мети за допомогою вирішення конкретних комунікаційних завдань. У політичному дискурсі, мета якого полягає в боротьбі за владу, специфіка комунікативного планування залежить від ситуації соціальної взаємодії комунікантів і особливостей мовної особистості політика, які відображаються на тактичних перевагах i, в результаті, відборі мовних засобів. Під мовною стратегією, виходячи з цього, ми будемо розуміти певну спрямованість мовної поведінки політика в певній ситуащії мовного спілкування, яка сприяє досягненню прогнозованої комунікаційної мети.

\section{Список літератури:}

1. Акінчиць Н.Г. Політичний дискурс як об’ект наукового аналізу. Культура народов Причернолорья. 2007. № 107. С. 72-76.

2. Кіщенко Н.Д. Вербалізація концепту WISDOM/MУДРICТЬ у дискурсі англомовної авторської казки : дис. ... канд. фрілол. наук : 10.02 .04 «Германські мови». Кийв, 2017. 189 с.

3. Мухарямова Л.М. Взаимодействие языка и политики в символических измерениях. Вестник Московского университета. Сер. 18. Социология и политология. 2002. № 2. С. 28.

4. Шейгал Е.И. Семиотика политического дискурса. 2001. С.42-61.

5. Шейгал Є.I. Семіотика политического дискурса. 2001. С. 24.

6. Foote, Joe S. Television Access and Political Power. The Networks, the Presidency and the «Loyal Opposition». New York : Praeger, 1990.

7. Trent, Judith S. and Friendenberg, Robert V. Political Campaign Communication Principles and Practices. New York : Praeger, 1991.

\section{References:}

1. Akynchits N.G. (2007) Politichniy diskurs yak ob'ekt naukovogo analizu [Political discourse as an object of scientific analysis]. Kultura narodov Prichernomorya, no. 107, pp. 72-76.

2. Kishchenko N.D. (2017) Verbalizatsiya kontseptu WISDOM/MUDRIST' u diskursi anglomovnoyi avtorskoyi kazky [Verbalization of the WISDOM / WISDOM concept in the discourse of an English-language author's fairy tale]: dis. ... kand. filol. nauk: 10.02. 04 "Germanski movy". Kyiv, 189 p.

3. Muharyamova L.M. (2002) Vzaimodeystvie yazyika i politiki v simvolicheskih izmereniyah [Interaction of language and politics in symbolic dimensions]. Vestnik Moskovskogo universiteta. Ser. 18. Sotsiologiya i politologiya, no. 2 , p. 28.

4. Sheygal E.I. (2001) Semiotika politicheskogo diskursa [Semiotics of Political Discourse].

5. Sheygal E.I. (2001) Semiotika politicheskogo diskursa [Semiotics of Political Discourse].

6. Foote, Joe S. (1990) Television Access and Political Power. The Networks, the Presidency and the «Loyal Opposition». New York: Praeger.

7. Trent, Judith S. and Friendenberg, Robert V. (1991) Political Campaign Communication Principles and Practices. New York: Praeger. 